\title{
EUROPEAN COMMISSION'S IDENTITY DURING BREXIT: A COMMUNICATION STRATEGY CHANGE ON TWITTER
}

\author{
Lluís MAS-MANCHÓN, PhD \\ Universitat Pompeu Fabra, Spain \\ lluis.mas@upf.edu \\ Nora Inka BIERMANN \\ Johannes Gutenberg-Universität Mainz, Germany \\ nora.biermann@googlemail.com \\ Frederic GUERRERO-SOLÉ, PhD \\ Universitat Pompeu Fabra, Spain \\ frederic.guerrero@upf.edu \\ David BADAJOZ-DÁVILA, PhD \\ Universitat Autònoma de Barcelona, Spain \\ david.badajoz@uab.cat
}

\begin{abstract}
The European Union (EU) was founded to promote peace, prosperity and other values between an increasing number of member states (European Commission, 2001). However, Brexit has activated a reputation crisis that reinforces Euroscepticism (Börzel; Risse, 2018). The objective of the study is to identify the differences in the semantic construction and thematic framing of the European Commission during a two-year period, previous to Brexit and after Brexit, on a sample of 4827 tweets posted by the European Commission. Findings show that in the period before Brexit, the EU is presented as an abstract political body, highly informative on major crisis, and reactively framing messages with values responsibility and solidarity. After Brexit, the EC adapted its communication strategy to foster a sense of belonging to the EU by underlining a common transnational European identity. These results show that EU is using Twitter strategically, and their communications as well as framings, values and lexicon have been different before and after Brexit on Twitter. This might apply to other channels as well.
\end{abstract}

Keywords: European Commission; Brexit; Political Communication; Euroscepticism; Framing Analysis; Social Media

\section{Introduction}

The European Union (EU) was founded to promote peace, prosperity, equality, rule of law, security, democracy, human dignity and human rights and freedom, between an increasing number 
of member states (European Commission, 2001). This endeavour merited the peace Nobel Prize in 2012. However, the EU is losing public support, mainly from European citizens, moving away from a "permissive consensus" to a "constraining dissensus" (Hooghe; Marks, 2009). The loss of public support is due to several economic, political and human factors such as the denial of the European constitution by France in 2005, the 2008 financial crisis, the ongoing refugee crisis or the Brexit (Bossetta et al., 2017; Guerra and Serricchio, 2014; Postelnicescu, 2016). These important factors reinforce the so-called Euroscepticism (Börzel and Risse, 2018; Guerra and Serricchio, 2014; Sojka and Vázquez, 2014) as opposed to Eurooptimism (Otero, 2013). This phenomenon implies an increasing public criticism to the EU, apathy and distrust towards national and EU institutions and a general drop in public support for the EU - "a genuine threat to European identity" (Krastev, 2017, p. 128).

This study focuses on the reputation crisis raised by the so-called Brexit, this is, the withdraw of the United Kingdom (UK) as a member state from the EU by activating article 50 of the EU treaty after holding a referendum on June $23^{\text {rd }}, 2016$. The referendum was won by those in favour of leaving the EU, an exit fully completed by January $1^{\text {st }}$ 2021(Hunt and Wheeler, 2016). "Brexit" has activated a "crisis of identity" (Navracsics, 2016) since it symbolized a change of trend in the EU's institutional structure, weakened the values of unity and concord, and put a threat on the EU's reputation (Caiani and Guerra, 2017; Galpin and Trenz, 2017). The EU communication, communication strategy and policies are facing ever since a challenge to uphold or redefine a consistent and strong European identity as well as manage the image and reputation of the new EU 27 under the scrutiny of today's public sphere.

The European Commission (EC) is the executive power or government of the EU political system (Kostadinova, 2017). It oversees the implementation of democratic and human rights policies (Youngs, 2004) and can be described as pro-European technocratic body being in favour of the continued existence of the EU laying stress on promoting European identity within the EU (European Commission, 2001).

During the celebration of the $60^{\text {th }}$ anniversary of the Treaties of Rome (European Commission, 2017), the president of the EC at that time Jean-Claude Juncker stated: "[ ...] it is time for a united Europe of 27 to shape a vision of its future", and suggested therewith that the remaining 27 states of Europe have to act jointly to secure its future existence" Formerly, the EC had put in a 2001 whitepaper that the Commission shall foster a sense of belonging through networks. Up to that 
moment, the Commission had plainly failed in giving access to information and communicating with "simple" citizens (Schlesinger, 1999; Meyer, 2002; Coenen, 2005). For instance, some authors have reported important inconsistencies on how the European identity is built in national TV news in France, Italy and the UK (Bayley and Williams, 2012; Bayley and Giuliani; 2012; Keulman and Koós, 2014; Thornborrow, Haarman and Duguid, 2012).

As part of the new communication strategy, the EU Commission created profiles in the social media channels YoutTube, Google+, Linkedin, Facebook and Twitter. Twitter is being used intensively to build and maintain the image of organizations and political actors (Heft, Wittwer and Pfetsch, 2017; Parmelee and Bichard, 2011). Twitter can be used, potentially, to implement an interactive online community (Grunig, 2009), similar to a two-way symmetrical model.

Framing, in social communication, consists in the selection of "some aspects of a reality and make them more salient in a communication", in order "to promote a particular problem definition, causal interpretation, moral evaluation and/or treatment recommendation" (Entman, 1993). Although Entman exposed the need to use a single and unique methodology, D'Angelo defended a multiparadigmatic view (cognitive, constructionist and critical) (D'Angelo, 2002).

Frames can be studied from the point of view of the media or their publics, and as dependent or independent variables (Scheufele, 1999). Research might as well as focus on selection, emphasis, and presentation (van Goorp, 2006) distinguishing between the event, related media and the frames. Framing has been proved to provoke different decisions with the same information (Kahneman and Tversky, 1984) and it operates as a form of metacommunication (Hallahan, 2008).

From the strategical communication viewpoint, organisations and political actors can conduct a one-way or a two-way communication; symmetrical or asymmetrical (Grunig, Hunt, 1984). Implementing social networks as part of the communication strategy, the EC has made a move from a potentially one-way asymmetrical model (Fawkes and Moloney, 2008) (Propaganda or Public Information models), towards a potential two-way symmetrical model, more persuasive and interactive (Grunig and Hunt, 1984; Grunig, 2009).

On these grounds, did the EC adapt its communication strategies on Twitter after Brexit? The promotion of a sense of belonging and the transmission of the European identity entails the dissemination of political and social values upon which European citizens can recognize themselves as a "we" (Keulman and Koós, 2014; Risse, 2010; Cerutti, 2008). The aim of this study 
is to find differences in the semantic construction and thematic framing of the European Commission before and after Brexit.

\section{Semantics and Frames of the European Commission on Twitter}

Politicians and political parties are using social media as relevant communication tools (Colleoni, Rozza and Arvidsson, 2014; Frame and Brachotte, 2015; Goldbeck, Grimes and Rogers, 2010; Jungherr, 2014; Stieglitz and Dang-Xuan, 2012). Particularly, Twitter is widely recognized by researchers as a central online space for political engagement (Bossetta et al., 2017; Colleoni, Rozza and Arvidsson, 2014; Heft, Wittwer and Pfetsch, 2017; Parmelee and Bichard, 2011; Trillo, 2017), as well as a paramount channel for news consumption (Brown, 2013; Kim, 2016), especially political news stories. However, most studies on Twitter focus on a single country (Casero-Ripollés, 2018). A remarkable exception is Trillo's work (2017) on how the EU Commission developed the Twitter anti-violence campaign \#SayNoStopVAW by using tweets and hashtags as channels for claims and slogans dissemination. However, research on how Twitter is used transnationally to communicate with publics in times of reputation threat or crisis is scarce up to date. Taking Brexit's turning point as the start of a serious ongoing crisis of reputation (Coombs, 2007), and giving the importance of verbal messages in political communication, we explore differences in the words and frames used by the EU Commission to represent the European identity in Twitter messages:

RQ1: Which words did the EU Commission use most frequently one year before and one year after Brexit to foster European-ness?

Since Brexit is an identity crisis for the EU government (Navracsics, 2016), academic literature discussing European identity refers to the term European-ness and the creation of a set of political and social values in which European citizens recognize themselves as a "we" (Keulman and Koós, 2014; Risse, 2010; Cerutti, 2008). Studies about cognitive interdependence showed that an intense

use of co-reference pronouns (we and $u s$ ) creates commitment (Agnew et al., 1998), increases a perception of closeness and enhances inclusiveness (Fitzsimons and Kay, 2004) together with direct addressing (you or your) of the reader creating closeness and solidarity (Brown and Gilman, 1960). Although the construction of the European identity is beyond the scope of this study, the use of these pronouns could indicate a more inclusive communication strategy (from a Public 
Information model towards a Persuasive model). Since the matter is a reputation threat to the European identity, we hypothesize that:

H1: The amount of co-reference and singular pronouns in the EU Commission tweets has increased after Brexit.

In addition, the EU Commission may set the grounds for this in-group feeling by interacting and fostering debate on Europeanization, on questions of common concern and by calling different nationalities for dialogue and participation (Björnehed and Erikson, 2018; Risse, 2010). For doing so, the EU Commission may also use metaphors, stylistic elements, personal tone, call-to-actions, or the use of different languages and concise hashtags to raise user engagement. A greater use of all these discursive elements can trigger the recipient's emotions and raise self-identification (Risse, 2010; Solis and Breakenridge, 2009; Supovitz and Reinkordt, 2017). This study explores some qualitative differences in the use of specific discursive elements:

RQ2: What type of language and discursive elements was the EC using before and after Brexit?

Thirdly, frames can be understood as "persistent patterns of cognition, interpretation, and presentation of selection, emphasis, and exclusion by which symbol handlers routinely organize discourse, whether verbal or visual" (Gitlin, 1980 p. 7). Thus, frames facilitate people to "locate, perceive, identify, and label" the circulating information around them (Goffman, 1974 p. 21). According to Iyengar (1991 p. 11), framing consists of the "subtle selection of certain aspects of an issue by the media to make them more important and thus to emphasize a particular cause of some phenomena".

The use of frames can foster the publics' sense of belonging and build on the organization's image in the public sphere (Hogg and Reid, 2006; Hornsey, 2008). Guerra and Serricchio define European identity as "a form of political and social identification" (2014: 278). Keulman and Koós expand the term to a "new sense of collective self-identification" (2014: 19). Formerly, collective identity had been conceptualized as the cohesive element that keeps a political system together and serves as a precondition for its long-term durability (Almond and Verba, 1963; Easton, 1965).

In the case of the European identity, authors have found four main frames in EU messages: values (Brewer and Gross, 2005; Halman, Sieben and vanZundert, 2014; Keulman and Koós, 2014), collectivism (Almond and Verba, 1963; Easton, 1965; Keulman and Koós, 2014), unified 
community (Kennedy, 2013; McCormick, 2010) and cultural diversity (Cerutti, 2008; Risse, 2010). Twitter can thus have "a profound effect on [framing the] political debate and public opinion" (Caiani and Guerra, 2017: 7), especially if connected with positive, negative or rather neutral events:

RQ3: Which frames were used in the EC tweets to depict European identity one year before and after Brexit? What type of messages -positive, negative or neutral, are those frames applied to?

Finally, this article discusses how differences in the words, discursive elements and frames used by the EC after Brexit may be indicative of the crisis response strategy applied in Twitter (if any) in this reputation threat. In this regard, the classical Situational Crisis Communication Theory (Coombs, 2007) formulated two categories of response strategies, denying responses (attack the accuser, explicit deny, scapegoat, excuse, justification, compensation or apology) or bolstering strategies (reminder, ingratiation and victimage).

\section{Method and sample}

The Twitter profile@EU_Commission was analysed one year before and after the Brexit turning point. The European Commission's social media team was contacted and kindly provided the 4.827 xlsx exported Tweets within the period of 2 years from $22^{\text {nd }}$ June 2015 until 22nd June 2017; pre-Brexit from $22^{\text {nd }}$ June 2015 to $22^{\text {nd }}$ June 2016 (2.311 Tweets) and post-Brexit from $23^{\text {rd }}$ June 2016 to $22^{\text {nd }}$ June 2017, totalling 2.401 Tweets.

This research presents a mixed method design in two phases: a lexicometry-semantic analysis on the one hand, and a framing analysis of tweets, on the other. The first phase consisted in a content analysis of the two samples to compare between the most frequently occurring words, in order to respond to the first research question and the hypothesis. These words were categorized as referring to three fields: democratic, social and political field; economics and money field; or co-reference and singular pronouns connected with the European affairs.

The second phase of the data analysis was the framing analysis, to answer to the second and third research questions. The most common frames depicting European identity were coded with the help of the MAXQDA software. We applied an open coding process (Neuman, 2003), starting with the four frames identified in the literature: values, collectivism, unified community and 
cultural diversity (Keulman and Koós, 2014; Kennedy, 2013; McCormick, 2010); as well as the words resulting from the analysis of lexicometry. Firstly, in order to assign tweets to these four categories, we build semantic trees based on the definition of these categories: the category values refer to democracy, social rights and equality; collectivism refers to the community with keywords such as common or shared; a unified community can be expressed with keywords such as united or together; and cultural diversity refers to different cultures, habits, traditions and the reference or use of different languages.

Secondly, the most frequently used words are grouped in themes to build larger categories as potential frames. The four a-priori frames (deductive method) along with the a-posteriori thematic categories of the keywords from the analysis of lexicometry (inductive method) are redefined in larger units from either merging existing units or slightly modifying the former ones, until all tweets before and after Brexit can be classified. The words, hashtags and discursive elements used by the EC are annotated (Heft, Wittwer and Pfetsch, 2017); tweets are categorized as connected with positive, negative or neutral events and cross-categorized with frames (Maheswaran and Meyers-Levy, 1990; McLeod and Detenber, 1999; Schuck and de Vreese, 2006). Cohen's $\kappa$ was run to determine if there was agreement between two coders of a subsample of the tweets. The results show a moderately strong agreement between the two coders, with $\kappa=.749, \mathrm{p}=.000$.

Finally, we conducted a chi-square test to determine whether the difference in the word and frames frequencies before and after Brexit was statistically significant.

\section{Results}

This research has performed an analysis of lexicometry (to respond to RQ1 and H1) and a framing analysis (to respond to RQ2 and RQ3). Firstly, the analysis of lexicometry compares the use of words by the EC in two semantic fields before and after Brexit.

In general, the EC did apply a different communication strategy after Brexit to engage with their publics, as the chi-square test showed that the quantitative difference in word frequencies before and after Brexit was statistically significant $(\mathrm{p}<.001)$. These differences are clear in both the democratic, social and political values field and the Economic and Money field (see Table 1). In the pre-Brexit period, main keywords are support, solidarity, humanitarian, rights, safety and security, which are semantically connected with crisis, as it will be subsequently seen. In the postBrexit period, apart from keeping solidarity, keywords change substantially: peace, future of 
Europe, stronger, united, our citizens. Concerning the economics and monetary field, keywords are maintained after Brexit although with a much lower frequency.

Table 1. Most frequent words pre- \& post-Brexit

\begin{tabular}{|c|c|c|}
\hline & Democratic, social \& political values & Economics \& money \\
\hline \multirow[t]{13}{*}{ Pre-Brexit } & Support (36) & Investment (113) \\
\hline & Solidarity (20) & Energy (37) \\
\hline & Humanitarian (19) & Sustainable (29) \\
\hline & Rights (18) & Development (20) \\
\hline & Safety (11) & EU funds \\
\hline & Security (11) & Jobs (18) \\
\hline & Responsibility (11) & Trade (16) \\
\hline & EU data protection (6) & Economic \& Monetary Union (7) \\
\hline & EU law (5) & Roaming (6) \\
\hline & Freedom (3) & Economic growth (3) \\
\hline & Peace (2) & \\
\hline & Equality (2) & \\
\hline & Our citizens (2) & \\
\hline \multirow[t]{14}{*}{ Post-Brexit } & Solidarity (25) & Investment (73) \\
\hline & Peace (24) & Trade (32) \\
\hline & Future of Europe (14) & Sustainable (24) \\
\hline & Stronger (12) & Innovation/defence (14) \\
\hline & United (12) & EU rules $(8)$ \\
\hline & Our citizens $(10)$ & Economic growth (4) \\
\hline & Democracy (8) & Low-carbon emissions (3) \\
\hline & Unity (6) & \\
\hline & Freedom (5) & \\
\hline & Security (5) & \\
\hline & Equality (4) & \\
\hline & Common values (4) & \\
\hline & Collective (2) & \\
\hline & Data protection (2) & \\
\hline
\end{tabular}


As shown in Figure 1, before Brexit the economics \& money category clearly dominates over democratic, social \& political values (249 and 120 words each). After Brexit, both fields are equalized as the former has a $36.6 \%$ decrease (158) and the latter maintains the amount of words (110). Regarding the use of co-reference and singular pronouns, there is a great increase (46\%) in the use those after Brexit (423 pre-Brexit and 784 post-Brexit). Particularly, the words we (158) and our (100) appeared more often than you (78) and your (70), and specially us (17), in the preBrexit period; in the post-Brexit years, the tweets analysed maintain the same order but doubling these figures for all pronouns: we (301), our (207), you (122), your (117) and us (37).

Figure 1. Analysis of lexicometry pre- \& post-Brexit.

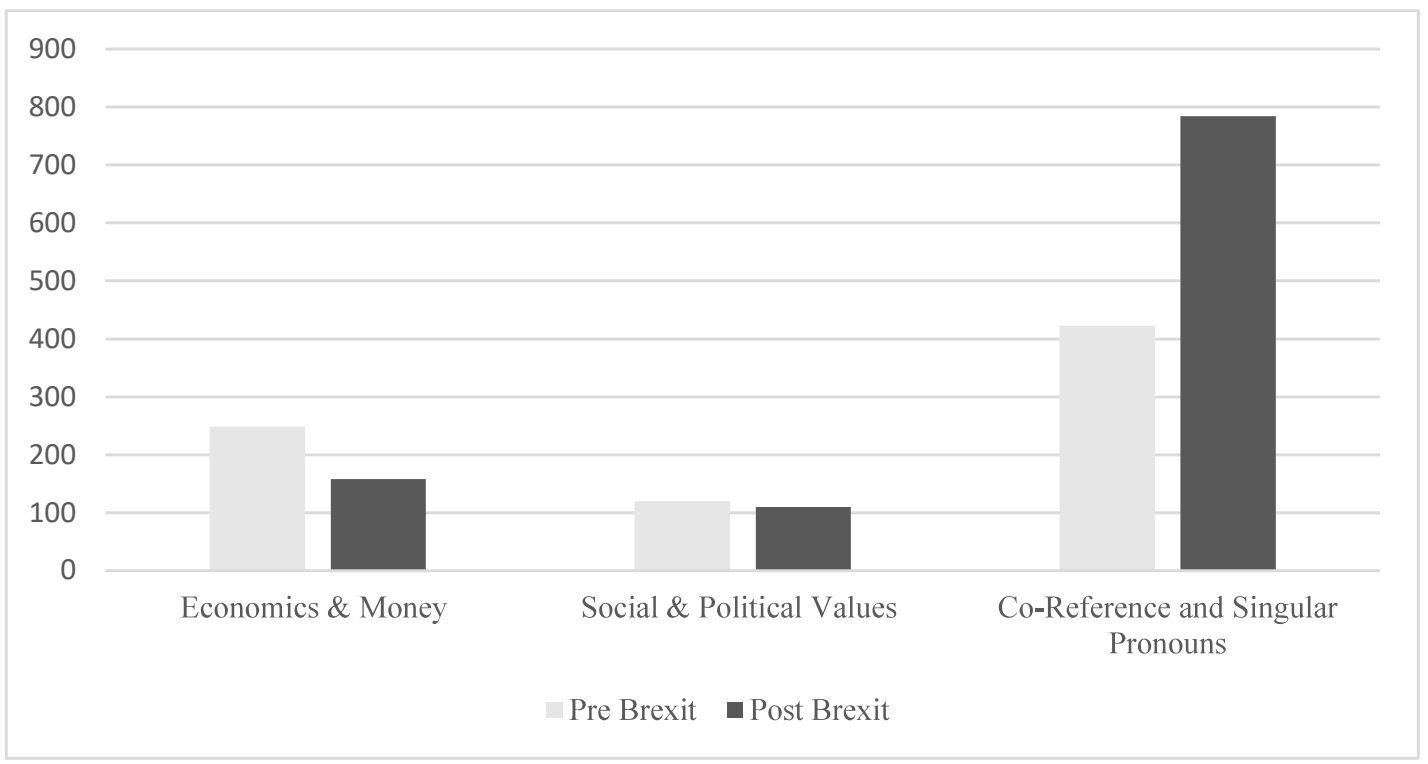

Secondly, we will present the results of the framing analysis. First, the framing analysis resulted in the identification of 5 frames concerning the European identity during the pre-Brexit period (see Table 2, "Refugee crisis category" being the 5th of them). These frames were made salient 116 times. Two main events -both negative- were framed: the refugee crisis was framed 35 times (30\%), mostly by either highlighting the EU as a collective and strong Union (18) or as support (8); and terrorism -terrorist attacks in Paris, Brussels, Manchester and London, framed 18 times (15\%), with a variety of frames: defence \& preservation, common problems, or responsibility \& solidarity. The rest of the times (63), the five frames were applied to neutral 
events, especially the support frame. The chi-square test shows that the quantitative difference in frames appearing before and after Brexit is statistically significant $(\mathrm{p}<.001)$.

As for the hashtags, the EU Commission gives great importance to the involvement of the online community in ongoing EU activities and political decisions by using the call-to-actions (e.g. "Have your say") or questions aiming at the engagement with the online community (What is your experience using your \#EU rights?, to engage and answer a questionnaire). Hashtags \#PublicConsultation and \#EUHaveYourSay are used to address directly the audience and to launch polls. Regarding the messages, they were not very engaging if related with terrorism ("Terrorists want to destroy our way of living together. We need to defend our values") or the refugee crisis ("We are taking decisive action on the refugee crisis" or "Our response to the refugee crisis will shape our history"). Finally, a personalized tone of voice was recognizable as for example at New Year's Eve season wishing or climate change as an opportunity to showcase EU's cultural background ("How do you say 'United for Climate' in your language?"). Tweets were published in Greek, French, German and English. Regarding the neutral events, the Commission phrased its goals in terms of citizens' attachment with EU institutions and commitment to build a strong future; and the EU citizens were given special importance and were described as the EU's codesigners: "Step by step Europe will solve problem collectively" or "We have the deal. Now we need to make it real".

Table 2. Frames in Twitter used by the EU pre- \& post-Brexit.

\begin{tabular}{lll}
\hline & Events & Frames \\
\hline Pre-Brexit & -Refugee crisis & -Support (humanitarian and financing) (8) \\
& & -Defence \& preservation (1) \\
& -EU as strong Union (18) \\
& - Common problems/values/ rights (2) \\
& -Responsibility \& solidarity (6) \\
& -Defence \& preservation (6) \\
& -Terrorism & -EU as strong Union (3) \\
& - Common problems/values/ rights (2) \\
& - Responsibility \& solidarity (7) \\
& - Support (humanitarian and financing) (30) \\
\hline
\end{tabular}




\section{NO. 35 / 2021}

-Defence \& preservation (11)

-EU as strong Union (14)

-Responsibility \& solidarity (8)

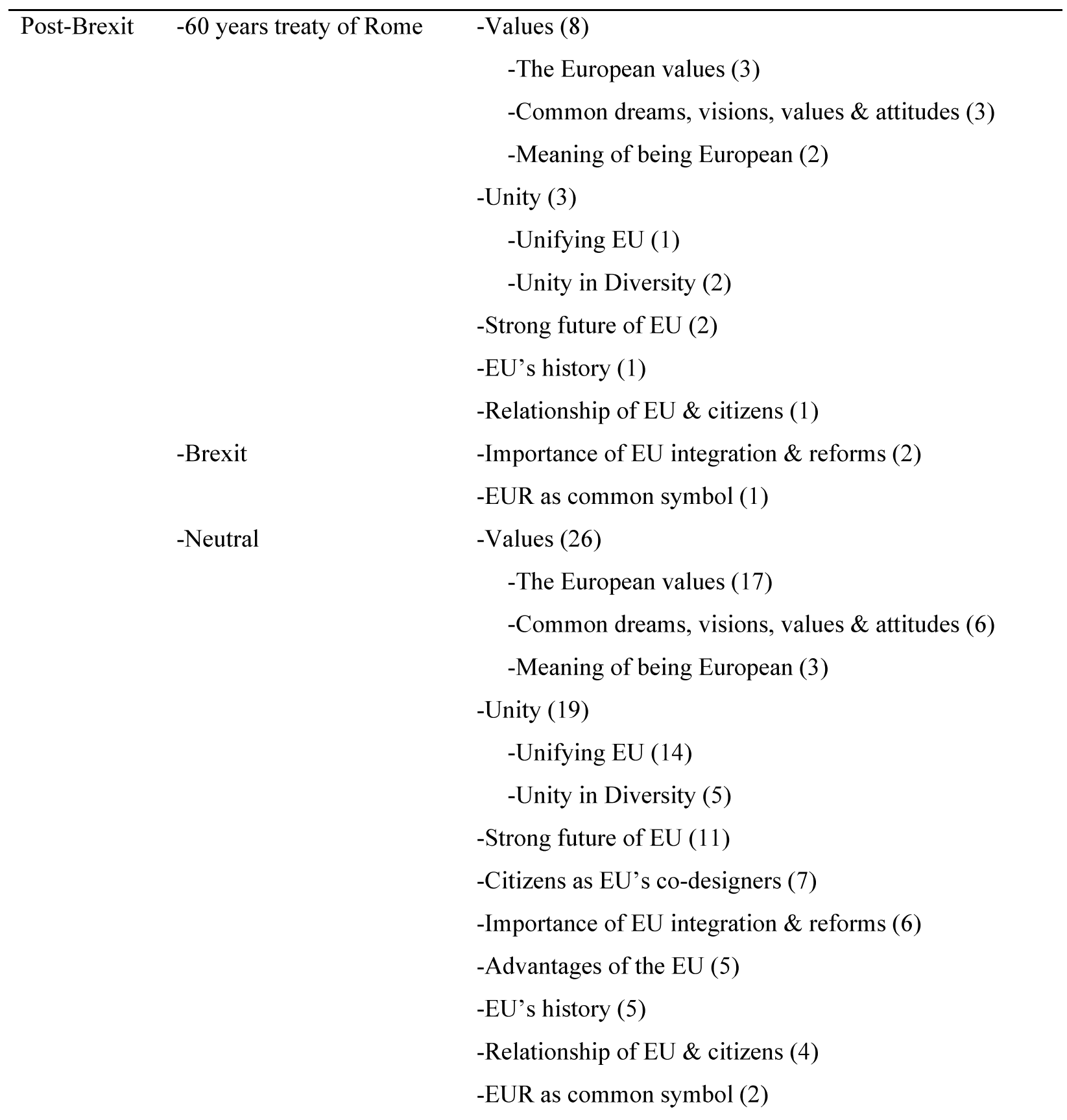

During the post-Brexit period, the framing analysis resulted in the identification of 9 frames concerning the European identity (see Table 2, "Neutral category" being the 9th of them), with two macro frames -values and unity- that present some subframes. These 9 frames were made 
salient 104 times. Two main events, one positive and the other negative, were framed: the 60 years treaty of Rome was framed 16 times (15\%), applying 5 out of the 9 frames; and Brexit was framed 2 times only by referring to the importance of the EU integration \& reforms (2) and the euro as a common symbol (1). The rest of times $(85,82 \%)$, these 9 frames were all applied to neutral events, especially European values, unifying the EU or a strong future. Apart from Brexit, which was almost ignored, the EU Commission also engaged in transmitting what being Europe means and what the EU stands for during the post-Brexit era.

In general, in the post-Brexit period, the EU used Twitter to engage users by applying influencers' strategies and a metaphorical language in both hashtags and messages. Many calls-toaction were utilized ("your voice matters"), questions were posed and feedback was required on EU implementations to involve the online community and foster dialogue (\#Eudialogues, \#EUHaveYourSay, \#Connectivity) and the European dignity (\#ThisIsTheEU, \#FutureofEurope). The Commission also tried to explain what must be avoided, cannot be supported or goes against EU values (\#Turkey - "No country can become member of the EU if it introduces the death penalty"). Additionally, metaphors like the comparison of the EU with marriage or "Build bridges, not walls" as well as expressions like "Europe means peace" depict Europe and reflect the importance and meaning of the EU in both a covert and direct way. Stylistic elements like repetitions were used ("Not fair, not sustainable, not acceptable"). Moreover, the Commission used a celebrity once, the German football player Philipp Lahm ("I feel European" says @philipplahm), to increase self-identification. Furthermore, audience engagement was stimulated through a GIF (about EU's history and current actions) and blog post competitions. Tweets were published in Italian, English, Spanish, French and Hungarian. Finally, during the post-Brexit period, European identity was increasingly connected with positive events (16 times post-Brexit against 0 preBrexit) or neutral events (85 against 63) (see Figure 2). 
Figure 2. Valence of events as connected with frames pre-Brexit \& post-Brexit.

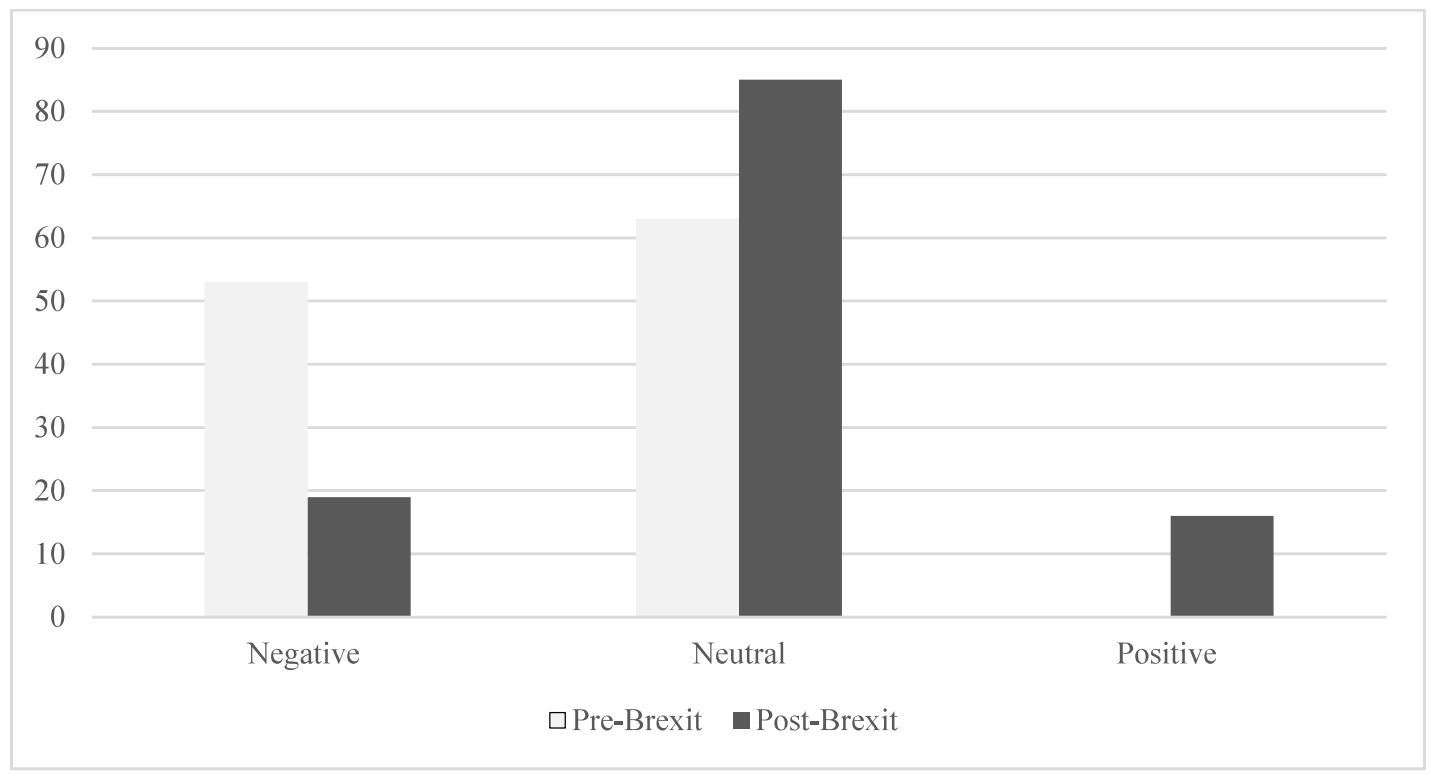

\section{Discussion}

In response to RQ1 (Which words did the EU Commission use most frequently one year before and one year after Brexit to foster European-ness?), words belonging to the field of economics \& money occurred more than twice as much as words expressing values in the pre-Brexit period. Hence, before Brexit, the EU Commission mainly addressed topics related to economic issues and primarily made use of Twitter as an informative channel to update the publics about ongoing activities and commitments of the EU (Gilpin, 2011). This suggests that European-ness was only slightly fostered before Brexit and that the most used words depicted the EU as a bureaucratic and abstract political body.

By contrast, during the post-Brexit era, findings reveal that the EU Commission aimed at creating a unified community (Kennedy, 2013; McCormick, 2010) because important "pillars" of the European identity (European Commission, 2001) were transmitted in the form of words such as "solidarity", "peace", "democracy", "freedom", "security" and "equality", which individuals can easily identify with (Keulman and Koós, 2014; Halman et al., 2014). Moreover, the words "collective", "common values", "our citizens" and "united", as well as "unity", create European identity because they relate to collectivism, a commonly shared value and EU unity. The transmission of values through language fosters Europeanness across members. This is essential 
for the formation of European identity and the related sense of belonging to the EU that should first be evoked in individuals to enable consequently their self-definition as part of the EU collective (Cerutti, 2008).

In addition, $\mathrm{H} 1$ is confirmed (The amount of co-reference and singular pronouns in the EU Commission tweets has increased after Brexit), as there is indeed a great increase in the use of coreference and singular pronouns after Brexit, which adds to the strategy of building a sense of belonging through language, especially the pronoun we. In response to RQ2 (What type of language and discursive elements was the EU Commission using before and after Brexit?), findings show a great variety use of call-to-actions, user engagement, concise hashtags and different European languages, as well as more personal tone and stylistic or rhetoric messages after-Brexit than before Brexit. This is in line with the need to build a European virtual space (Parmelee and Bichard, 2011) and the Europeanization as a public online sphere to debate questions of common concern (Risse, 2010).

Thus, after Brexit, the EU Commission attempted to strongly construct European-ness through the frequent use of co-reference and singular pronouns creating self-definition, commitment, solidarity, inclusiveness and a perception of closeness to the EU (Agnew et al., 1998; Fitzsimons and Kay, 2004), as well as through the reduced implementation of words referring to the EU as a political and abstract body, but referring to it as a social construct. The words used after-Brexit are in line with Juncker's (2017) statement after Brexit "[...] it is time for a united Europe of 27 to shape a vision of its future" and demonstrates that the EC transmits this mission on Twitter. After Brexit, the EU is depicted as a united community characterized by different cultures (Turner, 1975). By self-identifying with each nation, the Commission aims to simultaneously raise selfidentification with the EU (Halman et al., 2014; Risse, 2010; Cerutti, 2008).

In response to RQ3 (Which frames were used in the EU Commission tweets to depict European identity one year before and after Brexit? What type of messages, positive, negative or neutral, are those frames applied to?), the framing analysis plainly shows a turn from reactive, defensive, nonEuropean values in the pre-Brexit era (dominated by values responsibility and solidarity mainly, but also financing, humanitarian, union or rights) to a neat proactive European values (human rights, peace, equality...) (European Commission, 2001), but also dreams and visions, attitudes, bridges, symbols, diversity and history (Brewer and Gross, 2005). Whereas the pre-Brexit period tweets were framing negative events such as the Paris attacks or the refugee's crisis, the post- 
Brexit period tweets were framing positive or neutral events such as Anniversary of the Treaty of Rome or the representation of nations and cultures.

Particularly, the EU's Unity frame builds on the national and European identities are part of a larger Socio-Territorial Identity Complex frame (Keulman and Koós, 2014). This is a strategic indicator that EU Commission's strategy was not to be seen as a threat to national identities (Cerutti, 2008), but as inclusive body with a Genuine Political Entity frame (Duchesne and Frognier, 1998). Also, by highlighting the importance of reforms and referring to the EU's future, it becomes evident that the EU Commission focuses on the transmission of Europe's continuation and solutions to it after Brexit (Jora, 2018). Finally, the EU's future frame is built with references to common symbols such as the Euro currency, or the practical advantages of the EU. In general, the EC framed the Brexit three times only: to show the importance of reforms and the common market, with no reference to the crisis or reputation threat or minimizing the effects -justification response strategy (Coombs, 2007). Rather, the EC took advantage of many other issues and topics to ingratiate with European citizens with social, cultural, identity or rhetorical messages.

\section{Conclusions}

The aim of this research was to analyse the differences in the semantics and frames used by the EU Commission Twitter during the pre- and post-Brexit era, as well as to see if we can identify, in these differences, a more persuasive communication strategy. Brexit is taken as a turning point in the EU history because it destabilized the perception of the EU in the public sphere (Jora, 2018), hence comparison is used here as a case study to identify changes in the communication strategy in reaction to a unique crisis. Since the EU Commission's raison d'être is to promote the EU as a political construct and, as admitted publicly by top-level internal sources, its identity and unity are under serious threat after Brexit, this work expected the EU Commission to use Twitter strategically in order to manage a PR crisis of the European identity. The findings of the semantic and framing analysis reinforce this assumption and report the specific semantics and frames employed for that purpose.

In essence, the pre-Brexit semantic analysis showed that the EU Commission addressed more topics related to economic issues than to democratic, social \& political values and primarily made use of Twitter as an informative channel to update the public about ongoing activities or crisis. The technical presentation of the EU as a bureaucratic and abstract political body does not 
contribute to the EU citizens' a sense of belonging since people cannot well identify with information-based, political abstract bodies. Only when the very nature of the EU has been under threat (Brexit crisis), has the EU been active in communication campaigns and moving towards a more persuasive strategy via semantics and frames that are more unique of the European-ness.

Until the implementation of social networks, the Commission used a one-way communication strategy, distributing public information to their publics (Fawkes and Moloney, 2008). Parting from the results, we could argue that after Brexit the Twitter communication has been managed from a Public Information Model.

In this research we found that there have been changes towards a more inclusive language, using self-pronouns instead of an informative impersonal tone after the Brexit. Therefore, there has been a slight move towards a two-way asymmetric model adopting a more persuasive strategy.

This strategy has brought lexical references in Twitter to the EU as a supranational system based on fundamental values, and semantic constructions depicting the EU's economic and monetary characteristics. Moreover, after Brexit, co-reference and singular pronouns have been used more intensively to raise collective sense and a perception of closeness to the EU (Agnew et al., 1998; Fitzsimons and Kay, 2004; Brown and Gilman, 1960). The EU aims to have a clearer identity and to empower EU citizens by highlighting the importance of unity in diversity.

This research may be insightful for the EU Commission itself as findings report levels of consistency and news ideas within a long-term semantic and framed activity in Twitter (Caiani and Guerra, 2017), which can extensively shape how the publics engage with European politics. Nationalism can be curbed, and national differences be managed through Twitter by engaging with different cultures, the big community network and key influencers.

The globalisation and immigration phenomena are challenging the traditional ways these systems communicate and relate with publics. The communication of fundamental rights and values has a threefold objective: to preserve democratic and social structures, to comprehend different cultures and collectives, and to include them strategically as part of the (trans)'national' identity building. This research is not without limitations. First, the definition of frames was part of the content analysis, with some quantitative results but also mostly qualitatively-driven, so the validity of measures (thematic frames) should be tested in other case studies -Twitter communication of supranational institutions- and in longitudinal studies. Second, we did not examine pictures, content of the inserted links, audience reach or engagement and connections. 
Finally, the inclusion of fake news and their distortion of the EU's perception in the public sphere was not considered.

In the future, it would be fruitful for the development of strategic and organizational communication on transmitting identity, to conduct analyses on different supranational organizations in different cultural settings.

\section{References}

1. AGNEW, C. et al. (1998) Cognitive interdependence: Commitment and the mental representation of close relationships. Journal of Personality and Social Psychology, vol. 74, no 4, pp. 939-954.

2. Almond, G.A., VERBA, S. (1963) The Civic Culture: Political Attitudes in Five Nations. Princeton: Princeton University Press.

3. BAYLEY, P.,WILLIAMS, G. (2012) European Identity: What the Media Say. Oxford: Oxford Scholarship Online.

4. BAYLEY, P., GIULIANI, D. (2012) Semantic constructions of citizenship in the British, French, and Italian press. In: Bayley, P., Williams, G.(eds.) European Identity: What the Media Say. Oxford: Oxford Scholarship Online, pp. 1-45.

5. BJÖRNEHED, E., ERIKSON, J. (2018) Making the most of the frame: developing the analytical potential of frame analysis. Policy Studies, vol. 39, no 2, pp. 109-126.

6. BOSSETTA, M., DUTCEAC SEGESTEN, A., TRENZ, H.J. (2017) Engaging with European Politics Through Twitter and Facebook: Participation Beyond the National? In: Barisione, M., Michailidou, A.(eds.) Social Media and European Politics. Rethinking Power and Legitimacy in the Digital Era. Basingstoke: Palgrave Macmillan, pp. 53-76.

7. BÖRZEL, T.A., RISSE, T. (2018) From the euro to the Schengen crises: European integration theories, politicization, and identity politics. Journal of European Public Policy, vol. 25, no 1, pp. 83-108. 
8. BREWER, P.R., GROSS, K. (2005) Values, framing, and citizens' thoughts about policy issues: Effects on content and quantity. Political Psychology, vol. 26, no 6, pp. 929-948.

9. BROWN, R. (2013) Digital PR is dead: social goes mainstream. In: Brown, R., Waddington, S.(eds.) SHARE THIS TOO. More Social Media Solutions for PR Professionals. Chartered Institute of Public Relations (CIPR). Chichester: Wiley, pp. $1-9$.

10. BROWN, R., GILMAN, A. (1960) The pronouns of power and solidarity. In: Sebeok, T.A.(eds.) Style in language. Cambridge: MIT Press, pp. 253-276.

11. CAIANI, M., GUERRA, S. (2017) Euroscepticism, Democracy and the Media. Communicating Europe, Contesting Europe. Basingstoke: Palgrave Macmillan.

12. CASERO-RIPOLLÉS, A. (2018) Research on political information and social media: Key points and challenges for the future. El profesional de la información, vol. 27, no 5, pp. 964-974.

13. CERUTTI, F. (2008) Why political identity and legitimacy matter in the European Union. In: Cerutti, F., Lucarelli, S.(eds.) The search for a European identity: Values, policies, and legitimacy of the European Union. London: Routledge, pp. 3-22.

14. COENEN, C. (2005) Weblogs als Mittel der Kommunikation zwischen Politik und Bürgern - Neue Chancen für E-Demokratie? [Weblogs as a means of communication between politics and citizens - New opportunities for E-Democracy?]. Kommunikation (a) Gesellschaft, vol.6, pp.1-31.

15. COLLEONI, E., ROZZA, A., ARVIDSSON, A. (2014) Echo chamber or public sphere? Predicting political orientation and measuring political homophily in Twitter using big data. Journal of Communication, vol. 64, no 2, pp. 317-332.

16. COOMBS, W.T. (2007) Protecting organization reputations during a crisis: The development and application of situational crisis communication theory. Corporate Reputation Review, vol. 10, no 3, pp. 163-176.

17. D'ANGELO, P. (2002) News Framing as a Multiparadigmatic Research Program: a Response to Entman. Journal of Communication, vol. 52, no 4, pp. 870-888. 
18. DUCHESNE, S., FROGNIER, A.P. (1998) Is There a European Identity? In: Niedermayer, O., Sinnott, R.(eds.) Public Opinion and Internationalized Governance. New York: Oxford University Press.

19. EASTON, D. (1965) A Framework for Political Analysis. Englewood Cliffs: PrenticeHall.

20. ENTMAN, R.M. (1993) Framing: Toward clarification of a fractured paradigm. Journal of Communication, vol. 43, no 4, pp. 51-58.

21. EUROPEAN COMMISSION (2017) European Commission. White paper on the future of Europe and the way forward. Reflections and scenarios for the EU27. $\operatorname{COM}(2017) 2025 . \quad$ Available at: https://eur-lex.europa.eu/legalcontent/en/TXT/?uri=CELEX:52017DC2025 (accessed on 14 April 2021)

22. EUROPEAN COMMISSION (2001) European governance: A White Paper. COM 428. Available at: https://eur-lex.europa.eu/legalcontent/EN/TXT/?uri=celex:52001DC0428 (accessed on 14 April 2021).

23. FAWKES, J., MOLONEY, K. (2008) Does the European Union (EU) need a propaganda watchdog like the US Institute of Propaganda Analysis to strengthen its democratic civil society and free markets? Public Relations Review, vol. no 3, pp. 207214.

24. FITZSIMONS, G.M., KAY, A. C. (2004) Language and Interpersonal Cognition: Causal Effects of Variations in Pronoun Usage on Perceptions of Closeness. Personality and Social Psychology Bulletin, vol. 30, no 5, pp. 547-557.

25. FRAME, A., BRACHOTTE, G. (2015) Le tweet stratégique: Use of Twitter as a PR tool by French politicians. Public Relations Review, vol. 41, no 2, pp. 278-287.

26. GALPIN, C., TRENZ, H.J. (2017) The Spiral of Euroscepticism: Media Negativity, Framing and Opposition to the EU. In: Caiani, M., Guerra, S.(eds.) Euroscepticism, Democracy and the Media. Communicating Europe, Contesting Europe. Basingstoke: Palgrave Macmillan, pp. 49-72.

27. GITLIN, T. (1980) The whole world is watching. Berkeley: University of California Press. 
28. GILPIN, D.R. (2011) Working the Twittersphere. Microblogging as Professional Identity Construction. In: Papacharissi, Z.(ed.) A networked self. Identity, Community, and Culture on Social Network Sites. London-New York: Routledge, pp. 232-250.

29. GOFFMAN, E. (1974) Frame analysis: An essay on the organization of experience. Boston: Northeastern University Press.

30. GOLDBECK, J., GRIMES, J.M., ROGERS, A. (2010) Twitter use by the US Congress. Journal of the American Society for Information Science and Technology, vol. 61, no 8, pp. 1612-1621.

31. van GOORP, B. (2006) The constructionist approach to framing: bringing culture back in, Journal of Communication, vol. 67, no 2, pp. 869-870.

32. GRUNIG, J.E. (2009) Paradigms of global public relations in an age of digitalisation. PRism, vol. 6, no 2, 1-19.

33. GRUNIG, J.E., Hunt, T. (1984) Managing public relations. New York: Holt, Rinehart and Winston.

34. GUERRA, S., SERRICCHIO, F. (2014) Identity and Economic Rationality: Explaining Attitudes Towards the EU in a Time of Crisis. In: Stefanova, B.(ed.) The European Union Beyond the Crisis: Evolving Governance, Contested Policies, Disenchanted Publics. Lanham: Lexington Books, Rowman \& Littlefield, pp. 269-294.

35. HALMAN, L., SIEBEN, I., van ZUNDERT, M. (2014) Atlas of European Values. Trends and Traditions at the Turn of the Century. Tilburg: Brill.

36. HALLAHAN, K. (2008) Strategic Framing. In: Donsbach, W.(ed.) The International Encyclopedia of Communication. Chichester: Wiley.

37. HEFT, A., WITTWER, S., PFETSCH, B. (2017) Divided They Tweet? A Comparative Analysis of Twitter Networks of Pro- and Anti-EU Parties. In: Caiani, M., Guerra, S.(eds.) Euroscepticism, Democracy and the Media. Communicating Europe, Contesting Europe. Basingstoke: Palgrave Macmillan, pp. 195-218.

38. HOGG, M.A., REID, S.A. (2006) Social Identity, Self-Categorization, and the Communication of Group Norms. Communication Theory, vol. 16, no 1, pp. 7-30.

39. HOOGHE, L., MARKS, G. (2009) A Postfunctionalist Theory of European Integration: From Permissive Consensus to Constraining Dissensus. British Journal of Political Science, vol. 39, no 1, pp. 1-23. 
40. HORNSEY, M.J. (2008) Social Identity Theory and Self-categorization. Theory: A Historical Review. Social and Personality Psychology Compass, vol. 2, no 1, pp. 204222.

41. HUNT, A., WHEELER, B. (2016) Brexit: All you need to know about the UK leaving the EU News Sport Weather Shop Earth Travel, London: BBC. Available at: https://www.bbc.com/news/uk-politics-32810887 (accessed on 14 April 2021).

42. IYENGAR, S. (1991) Is anyone responsible? How television frames political issues. Chicago: University of Chicago Press.

43. JORA, L. (2018) Brexit - Public diplomacy reform and counter-reform of the European Union. Romanian Review of Political Sciences \& International Relations, vol. 15, no 1, pp. 17-24.

44. JUNGHERR, A. (2014) The Logic of Political Coverage on Twitter: Temporal Dynamics and Content. Journal of Communication, vol. 64, no 2, pp. 239-259.

45. KAHNEMAN, D., TVERSKY, A. (1984) Choices, values, and frames. American Psychologist, vol. 39, no 4, pp. 341-350.

46. KENNEDY, R. (2013) The role of supranational identity in promoting democratic values. European Union Politics, vol. 14, no 2, pp. 228-249.

47. KEULMAN, K., KOÓS, A.K. (2014) European Identity: Its Feasibility and Desirability. Plymouth: Lexington Books.

48. KIM, C.M. (2016) Social media campaigns: strategies for public relations and marketing. New York: Routledge.

49. KOSTADINOVA, V. (2017) The European Commission and the Transformation of EU Borders. Basingstoke: Palgrave Macmillan.

50. KRASTEV, I. (2017) After Europe. Philadelphia: University of Pennsylvania Press.

51. MAHESWARAN, D., MEYERS-LEVY, K. (1990) The Influence of Message Framing and Issue Involvement. Journal of Marketing Research, vol. 27, no 3, pp. 361-367.

52. MCCORMICK, J. (2010) Europeanism. Oxford: Oxford University.

53. MCLEOD, D.M., DETENBER, B.H. (1999) Framing Effects of Television News Coverage of Social Protest. Journal of Communication, vol. 49, no 3, pp. 3-23. 
54. MEYER, C. (2002) Political Legitimacy and the Invisibility of Politics: Exploring the European Union's Communication Deficit. Journal of Common Market Studies, vol. 37, no 4, pp. 617-639.

55. NAVRACSICS, T. (2016) Beyond Policies: A Crisis of Identity. Elte Law Journal, vol. 6, pp. 9-17.

56. NEUMAN, W.L. (2003) The Meanings of Methodology: Social Research Methods. Boston: Allyn \& Bacon.

57. OTERO FELIPE, P. (2013) Integración europea y opinión pública en el sur de Europa: un análisis del eurooptimismo [European integration and public opinion in southern Europe: an analysis of Eurooptimism]. Revista Española de Ciencia Política, vol. 19, pp. 137-167.

58. PARMELEE, J.H., BICHARD, S. L. (2011) Politics and the Twitter Revolution. How Tweets Influence the Relationship between Political Leaders and the Public. Plymouth: Lexington Books.

59. POSTELNICESCU, C. (2016) Europe's New Identity: The Refugee Crisis and the Rise of Nationalism. Europe's Journal of Psychology, vol. 12, no 2, pp. 203-209.

60. RISSE, T. (2010) A Community of Europeans? Transnational Identities and Public Spheres. Ithaca: Cornell University Press.

61. SCHEUFELE, D.A. (1999) Framing as a theory of media effects. Journal of Communication, vol. 49, pp. 103-122.

62. SCHLESINGER, P. (1999) Changing Spaces of Political Communication: The Case of the European Union. Political Communication, vol. 16, no 3, pp. 263-279.

63. SCHUCK, A.R.T., de VREESE, C.H. (2006) Between risk and opportunity. News Framing and its Effects on Public Support for EU Enlargement. European Journal of Communication, vol. 21, no 1, pp. 5-32.

64. SOJKA, A., VÁZQUEZ, R. (2014) Identidad europea en el sur de Europa: Un análisis comparado de las percepciones de las élites y opinión pública en España y Portugal [European identity in southern Europe: A comparative analysis of the perceptions of elites and public opinion in Spain and Portugal]. Revista Española de Ciencia Política, vol. 36, pp. 89-114. 
65. SOlis, B., BREAKENRIDGE, D.K. (2009) Putting the Public Back in Public Relations. How Social Media is Reinventing the Aging Business of PR. New Jersey: Pearson Education LDT.

66. STIEGLITZ, S., DANG-XUAN, L. (2012) Social Media and Political Communication - A Social Media Analytics Framework. Social Network Analysis and Mining, vol. 3, no 4, pp. 1277-129.

67. SUPOVITZ, J., REINKORDT, E. (2017) Keep Your Eye on the Metaphor: The Framing of the Common Core on Twitter. Education Policy Analysis Archives, vol. 25, no 30 .

68. THORNBORROW, J., HAARMAN, L., DUGUID, A. (2012) Discourses of European identity in British, Italian, and French TV news. In: Bayley, P., Williams, G.(eds.) European Identity: What the Media Say. Oxford: Oxford Scholarship Online, pp. 84116.

69. TRILLO, T. (2017) Communicating Anti-Violence Policy on Twitter: The European Commission and \#SayNoStopVAW. Styles of Communication, vol. 9, no 1, pp. 9-24.

70. TURNER, J.C. (1975) Social comparison and social identity: Some prospects for intergroup behaviour. European Journal of Social Psychology, vol. 5, no 1, pp. 5-34.

71. YOUNGS, R. (2004) Normative dynamics and strategic interests in the EU's external identity. Journal of Common Market Studies, vol. 42, no 2, pp. 415-435. 